\title{
Zmiany w systemie wyrównywania dochodów samorządu województwa
}

\author{
Changes in the local government \\ income compensation scheme
}

Streszczenie. Istotną przyczyną wymuszającą zmiany w obecnym systemie finansowania samorządów terytorialnych są wady wyrównywania poziomego, na szczeblu powiatowym i wojewódzkim wyrażające się w nadmiernej redystrybucji dochodów. Zaproponowane obecnie przez ustawodawcę zmiany w systemie wyrównywania dochodów jednostek samorządu terytorialnego wynikają z konieczności wdrożenia zaleceń Trybunału Konstytucyjnego. Według Trybunału mechanizm wyrównywania poziomego polegający na przekazywaniu środków z samorządów bogatszych do biedniejszych za pomocą dokonywania wpłat na zwiększenie kwoty subwencji powinien stanowić instytucję wyjątkową i jedynie uzupełniać mechanizm wyrównywania pionowego z budżetu państwa.

Założeniem nowelizowanej ustawy jest wprowadzenie takiego mechanizmu korekcyjno-wyrównawczego, który nie doprowadzi do obniżenia poziomu dochodów województw dokonujących wpłat. Zaproponowane rozwiązania mają jednak charakter tymczasowy na okres trzech lat. Trwałe rozwiązania systemowe muszą 
być dostosowane do reform gospodarczych, które będą miały wpływ na poziom dochodów jednostek samorządu terytorialnego.

Słowa kluczowe: wyrównywanie dochodów samorządów terytorialnych; kryteria subwencjonowania samorządów terytorialnych; dotacje.

\begin{abstract}
The significant factor that enforces changes in the current local government financing system are some defects in the horizontal compensation scheme at the poviat and voievodship levels, expressed in the overdue redistribution of income. The changes in the local government income compensation scheme, as proposed recently by the legislator, result from the necessity to implement the recommendations of the Constitutional Tribunal. According to the Tribunal, the horizontal compensation scheme, based on transferring funds from wealthier local governments to poorer ones by the means of making payments for increasing the values of subsidies, should make for an exceptional measure and may only supplement the system of vertical compensating from the Treasury. The intention that stands behind the new draft is to introduce such a corrective and compensating mechanism that would not bring about reduction of incomes achieved by the contributing voivodeships. The proposed solutions would be temporary only - for the period of three years. Permanent solutions, however, need to be adopted to economical reforms, which will have an effect on incomes achieved by local government units.
\end{abstract}

Keywords: local government income compensation, criteria for subsidizing local governments, subsidies.

\title{
1. Wstęp
}

Regulacje prawne dotyczące systemu wyrównywania dochodów budżetowych jednostek samorządu terytorialnego wyznaczają zakres ich samodzielności finansowej i decydują o relacjach między państwem a władzami lokalnymi. Zastosowane rozwiązania prawne w tym zakresie określają pozycję samorządów w strukturach państwa.

Należy rozważyć, jakie kryteria i mierniki byłyby optymalne w obecnym modelu subwencjonowania terytorialnych związków publicznoprawnych w Polsce. Dobór odpowiednich kryteriów wymaga ich dostosowania do całościowej koncepcji dotyczącej struktury źródeł 
dochodów oraz rodzajów wykonywanych zadań samorządów terytorialnych i powinien uwzględniać szereg czynników, m.in. możliwości dochodowe danej jednostki samorządu terytorialnego, jej wydatki, a także sytuację ekonomiczną i społeczną państwa.

Istotną przyczyną wymuszającą zmiany w obecnym systemie finansowania samorządów terytorialnych są wady wyrównywania poziomego, na szczeblu powiatowym i wojewódzkim wyrażające się w nadmiernej redystrybucji dochodów.

\section{Zalecenia Trybunału Konstytucyjnego dotyczące systemu wyrównywania dochodów jednostek samorządu terytorialnego i poglądy literatury}

Zaproponowane obecnie przez ustawodawcę zmiany w systemie wyrównywania dochodów jednostek samorządu terytorialnego wynikają z konieczności wdrożenia zaleceń Trybunału Konstytucyjnego. Konstytucja z dnia 2 kwietnia 1997 r. ${ }^{1}$ odnosi się do systemu wyrównywania dochodów w art. 167 ust. 2. Stanowi on, iż dochodami jednostek samorządu terytorialnego są ich dochody własne oraz subwencje ogólne i dotacje celowe z budżetu państwa. Przepisy Konstytucji nie odnoszą się w sposób bezpośredni do wyrównywania poziomego, który jest realizowany za pomocą wpłat korekcyjno-wyrównawczych przeznaczonych na zwiększenie kwoty subwencji ogólnej.

Zgodnie z art. 29 ustawy o dochodach jednostek samorządu terytorialnego ${ }^{2}$ gminy, w których wskaźnik dochodów podatkowych na mieszkańca w gminie (G) jest większy niż 150\% wskaźnika dochodów podatkowych dla wszystkich gmin (Gg), dokonują wpłat do budżetu państwa z przeznaczeniem na część równoważącą subwencji ogólnej dla

Dz.U. Nr 78, poz. 483 ze zm.

Ustawa z dnia 13 listopada 2003 r. o dochodach jednostek samorządu terytorialnego (Dz.U z 2016 r., poz. 198). 
gmin. Wysokość rocznej wpłaty jest uzależniona od liczby mieszkańców gmin oraz nadwyżki wskaźnika $\mathrm{G}$ ponad $150 \%$ wskaźnika Gg.

$\mathrm{Na}$ mocy art. 30 powiaty, w których wskaźnik dochodów podatkowych na mieszkańca powiatu (P) jest większy niż 110\% wskaźnika określającego dochody podatkowe dla wszystkich mieszkańców powiatów (Pp), dokonują wpłat do budżetu państwa z przeznaczeniem na część równoważącą subwencji ogólnej dla powiatów. Przy obliczeniach kwoty należnej wpłaty brane są pod uwagę takie kryteria jak liczba mieszkańców powiatu oraz nadwyżka wskaźnika P ponad 110\% wskaźnika Pp.

Województwa są objęte takim samym obowiązkiem dokonywania wpłat do budżetu, ale tylko do końca 2016 r. Na podstawie art. 70a w roku 2015 i 2016 wpłat do budżetu, z przeznaczeniem na część regionalną subwencji ogólnej dla województw dokonują województwa, w których wskaźnik (W) dochodów podatkowych na mieszkańca województwa jest większy niż 125\% wskaźnika dochodów podatkowych dla wszystkich województw. Kryteria stosowane przy ustalaniu kwoty rocznej wpłaty są analogiczne jak w przypadku gmin i powiatów. Jednak nowelą do ustawy o dochodach jednostek samorządu terytorialnego ${ }^{3}$ ustawodawca wprowadził w 2015 r. dla wpłat dokonywanych przez województwa maksymalny poziom, gdyż nie mogą one przekroczyć 35\% dochodów podatkowych województwa z roku poprzedzającego rok bazowy.

Art. 31 zobowiązujący do dokonywania wpłat województwa, w których wskaźnik dochodów podatkowych na mieszkańca województwa jest większy od 110\% wskaźnika (Ww) dochodów podatkowych na mieszkańca wszystkich województw został uchylony na skutek wyroku Trybunału Konstytucyjnego z dnia 4 marca 2014 r. ${ }^{4}$

Na mocy nowego art. 70a kwota rocznej wpłaty województwa zależy od liczby mieszkańców województwa oraz wysokości nadwyżki wskaźnika dochodów podatkowych na jednego mieszkańca w województwie (W) ponad 125\% wskaźnika dochodów podatkowych

3 Ustawa z dnia 23 października 2014 r. o zmianie ustawy o dochodach jednostek samorządu terytorialnego (Dz.U z 2014 r., poz. 1574).

$4 \quad$ Dz.U. z 2014 r., poz. 348. 
dla wszystkich województw (Ww). Jest ona obliczana w dwóch przedziałach. W pierwszym z nich wskaźnik W nie jest większy niż 150\% wskaźnika Ww, a w drugim wskaźnik W przekracza 150\% wskaźnika Ww.

Wprowadzona też została możliwość obniżenia kwoty wpłat o 10\%, jeżeli dochody województwa dokonującego wpłat z tytułu udziału we wpływach z podatku dochodowego od osób fizycznych i we wpływach z podatku dochodowego od osób prawnych ustalone jako suma tych dochodów uzyskach w drugim półroczu roku bazowego i w pierwszym półroczu roku bazowego będą niższe o więcej niż 10\% w porównaniu do tych dochodów uzyskanych łącznie w drugim półroczu roku poprzedzającego rok bazowy i w pierwszym półroczu roku bazowego.

Kolejna nowelizacja ustawy o dochodach jednostek samorządu terytorialnego ${ }^{5}$ przedłużyła zasady dokonywania wyżej wymienionych wpłat do końca 2016 r. oraz wprowadziła regulacje dotyczące zmniejszania bądź zwiększania części regionalnej subwencji ogólnej w zależności od tego, czy kwota wpłat obliczona na podstawie art. 70a zostanie zmniejszona.

Oceniając system wyrównywania poziomego, Trybunał Konstytucyjny stwierdził, że „konstrukcja mechanizmu korekcyjno-wyrównawczego - jako instytucji wyjątkowej w określonym w Konstytucji systemie dochodów JST - powinna zawierać gwarancje zachowania istotnej części dochodów własnych województw na realizację ich zadań własnych. Badając kryteria identyfikacji samorządów najbogatszych i najbiedniejszych, Trybunał Konstytucyjny stwierdził, że w ustawie o dochodach jednostek samorządu terytorialnego nie istnieje jednolity system kryteriów uwzględniający zarówno różnice w ukształtowaniu źródeł dochodów własnych, jak i podstawowe wydatki - na podstawie którego można byłoby ustalić rzeczywistą sytuację finansową poszczególnych województw. W obecnym kształcie normatywnym według innych kryteriów ustanawia się samorządy najbogatsze (art. 31 ust. 1 ustawy o dochodach j.s.t. - kryterium

5 Ustawa z dnia 5 sierpnia 2015 r. o zmianie ustawy o dochodach jednostek samorządu terytorialnego (Dz.U. 2015 r. poz. 1293). 
dochodów podatkowych), a według innych ustala się beneficjentów wpłat, którymi powinny być samorządy biedniejsze (kryteria określone w art. 25 ustawy o dochodach j.s.t.) (...). Wydaje się zatem słuszne stwierdzenie, że oba mechanizmy, tj. system wpłat i wypłat wyrównawczych, funkcjonują niezależnie od siebie, chociaż działają na tej samej materii dochodów JST. Dla właściwej realizacji zasady solidarności przy konstruowaniu kryteriów identyfikacji samorządów najbogatszych oraz najbiedniejszych, ustawodawca powinien ukształtować jednolite kryteria, biorąc pod uwagę zarówno pełen katalog dochodów, jak i potrzeby wydatkowe różniących się pod wieloma względami JST, aby w sposób jak najbardziej obiektywny i pełny odzwierciedlić potencjał dochodowy i ekonomiczny jednostek samorządu terytorialnego. Tylko tak skonstruowany system może uzasadniać uszczuplenie - najistotniejszych z punktu widzenia zasady samodzielności i decentralizacji - dochodów własnych””.

Podobne poglądy były wypowiadane $\mathrm{w}$ literaturze przedmiotu. Stwierdzano, że wpłaty korekcyjno-wyrównawcze nie stanowią uzupełniającego względem subwencji wyrównawczej mechanizmu wyrównywania potencjału dochodowego jednostek samorządu terytorialnego. Z uwagi na wysoką redystrybucję dochodów, zwłaszcza na szczeblu powiatowym i wojewódzkim, jaka następuje w związku z ich dokonywaniem, uznano, że stały się one równorzędnym w odniesieniu do pionowego instrumentem równoważenia budżetów lokalnych. Prowadzi to do wniosku, że zadanie niwelowania rażącej niewspółmierności dochodów jednostek samorządu terytorialnego do obowiązku realizacji zadań publicznych przejęły od państwa samorządy terytorialne ${ }^{7}$.

Słuszne wydaje się twierdzenie mówiące o tym, że ocena poziomego systemu wyrównywania dochodów jednostek samorządu terytorialnego winna uwzględniać istnienie pierwotnego mechanizmu wyrównywania pionowego, czyli części wyrównawczej subwencji ogólnej, finansowanej z budżetu państwa. System wyrównywania poziomego polegający na przekazywaniu środków z samorządów bogatszych do biedniejszych

\footnotetext{
Wyrok Trybunału Konstytucyjnego z dnia 4 marca 2014 r. sygnatura akt K 13/11.

M. Bogucka-Felczak, System korekcyjno-wyrównawczy - postulaty de lege ferenda, „Finanse Komunalne” 2014, nr 1-2, s. 99.
} 
powinien jedynie uzupełniać mechanizm wyrównywania pionowego z budżetu państwa ${ }^{8}$.

W literaturze wskazywano na asystemowość wyrównywania dochodów jednostek samorządu terytorialnego. Zwracano uwagę na odmienną rolę wpłat na poziomie gminnym, powiatowym i wojewódzkim. Bowiem wyrównywanie dochodów gmin ma rzeczywiście charakter systemu korekcyjnego. Natomiast na poziomie powiatowym i wojewódzkim wpłaty prowadzą do redystrybucji niemal jednej piątej wszystkich dochodów podatkowych. Powiaty, które zgodnie z kryteriami ustawowymi są uznawane jako „najbogatsze”, mają w rzeczywistości znacznie niższe dochody niż jednostki, na rzecz których dokonują wpłat ${ }^{9}$.

Do negatywnych cech systemu ustalania wpłat do budżetu państwa zaliczono również brak mechanizmu uwzględniania zmian w dochodach jednostek samorządu terytorialnego $\mathrm{z}$ powodu zmian cyklicznych w gospodarce, m.in. ze względu na strukturę dochodów budżetowych z dominującym udziałem dochodów uzależnionych od warunków makroekonomicznych ${ }^{10}$.

Zdaniem Trybunału Konstytucyjnego „wyjątek od systemu stworzonego przez art. 167 ust. 2 Konstytucji ma duży ciężar gatunkowy, gdyż nie tylko zmienia system wyposażenia samorządu w dochody kosztem władz i organów centralnych, lecz nadto ogranicza stymulacyjne, pobudzające samodzielność i odpowiedzialność za własne działania znaczenie dochodów własnych. Nie można zatem z instytucji wpłat wyrównawczo-korekcyjnych stworzyć systemu przeciwnego do tego, który został ustanowiony przez art. 167 ust. 2 Konstytucji, tzn. systemu korygowania tego, co pierwotnie władze centralne dały samorządom -

8 A. Nelicki, Uwagi na temat konstytucyjności mechanizmu „Janosikowego” w świetle wyroku Trybunału Konstytucyjnego z 25 lipca 2006 r., [w:] M. Izdebski, A. Nelicki, I. Zachariasz (red. nauk.), Finanse komunalne a Konstytucja, Studia i Materiały Trybunału Konstytucyjnego, Warszawa 2012, s. 260.

9 D. Kamińska, A. Nelicki, Asystemowość wyrównywania dochodów jednostek samorzq̨du terytorialnego, [w:] M. Izdebski, A. Nelicki, I. Zachariasz (red.), Finanse komunalne a Konstytucja, Warszawa 2012, s. 178 i 183.

10 M. Miesztalski, Dysfunkcje w systemie wyrównywania dochodów jednostek samorzqdu terytorialnego, [w:] M. Izdebski, A. Nelicki, I. Zachariasz (red. nauk.), Finanse komunalne a Konstytucja, Warszawa 2012, s. 195. 
wywiązując się ze swoich konstytucyjnych powinności. Tego rodzaju korekta wyrównawcza, której źródłem są wpłaty pobierane od niektórych samorządów, już sama przez się jest dowodem, że podział pierwotny, czyli ustawowy proces wyposażania samorządu w dochody własne, subwencje i dotacje - wynikający z obowiązków konstytucyjnych - jest oceniany przez tę samą władzę ustawodawczą jako niewystarczający. Jego efektem jest bowiem możliwość powstawania - zdaniem tego samego ustawodawcy - rażącej niewspółmierności potencjału finansowego poszczególnych samorządów"11.

W tym samym wyroku z 2006 r. Trybunał Konstytucyjny uznał za konstytucyjnie dopuszczalne funkcjonowanie wpłat wyrównawczo-korekcyjnych pod określonymi warunkami:

- ustawowego uregulowania w sposób kategorialny podstaw pobrania i zasad podziału,

- celowego przeznaczenia na potrzeby innych samorządów związane ze skutkami finansowania obligatoryjnych zadań własnych, a nie na potrzeby ogólnopaństwowe,

- określania wysokości wpłat w taki sposób, by zmniejszały one dochody własne samorządów bogatszych tylko w zakresie niezbędnym, nie niwecząc zarazem znaczenia tych dochodów,

- nadania wpłatom charakteru uzupełniającego mechanizmu wyposażenia samorządów w dochody, w sposób określony w art. 167 ust. 2 Konstytucji - nie zaś jego zastępowania.

System dokonywania wpłat wyrównawczo-korekcyjnych nie może również naruszać konstytucyjnej zasady adekwatności. Trybunał Konstytucyjny, odnosząc się do zasady odpowiedniości, stwierdził, że „art. 167 ust. 1 Konstytucji nakłada na ustawodawcę obowiązek zachowania proporcji między wysokością dochodów jednostek samorządu terytorialnego, a zakresem przypadających im zadań. Ocena zachowania tej proporcji musi uwzględniać całokształt dochodów jednostek samorządu terytorialnego danego szczebla. Akt normatywny mógłby zostać uznany za sprzeczny z art. 167 ust. 1 konstytucji tylko wtedy,

11 Wyrok Trybunału Konstytucyjnego z dnia 25 lipca 2006 r., K30/04. 
gdyby ogólny poziom dochodów jednostek samorządu terytorialnego, jaki wynika $\mathrm{z}$ obowiązującego ustawodawstwa uniemożliwił efektywną realizację zadań powierzonych tym jednostkom ${ }^{12}$ ".

Dokonywanie wpłat korekcyjno-wyrównawczych nie może więc negatywnie wpływać na poziom zadań wykonywanych przez jednostki samorządu terytorialnego. Doktryna postuluje, aby instytucję wpłat uznawać za instytucję wyjątkową, uzasadnioną przejściowo zjawiskiem rażącej niewspółmierności potencjału finansowego poszczególnych samorządów $^{13}$, a także oddzielić je od subwencji pochodzącej z budżetu państwa oraz zapewnić ustawowo inną pozycję Komisji Wspólnej przy ustalaniu kryteriów podziału środków pochodzących z wpłat wyrównawczych samorządów ${ }^{14}$.

Zmiany wymaga formuła ustalania subwencji wyrównawczej. Zdaniem doktryny należyte funkcjonowanie subwencji wyrównawczej jest zależne od właściwie wybranego i ustabilizowanego zakresu dochodów podatkowych będących podstawą jej obliczenia ${ }^{15}$.

\section{Proponowane zmiany ustawowe systemu korek- cyjno-wyrównawczego dochodów województw}

Projekt ustawy o zmianie ustawy o dochodach jednostek samorządu terytorialnego ${ }^{16}$ proponuje przedłużenie obecnie obowiązujących zasad dokonywania wpłat przez województwa do budżetu państwa. Zaproponowane $\mathrm{w}$ projekcie $\mathrm{z}$ dnia 1 lipca $2016 \mathrm{r}$. rozwiązania prawne mają zapewnić województwom dochody na poziomie porównywalnym z tym, który osiągały one przed dniem 14 listopada 2014 r., czyli przed

12 Wyrok Trybunału Konstytucyjnego z dnia 16 marca 1999 r., K 35/98, Orzecznictwo Trybunału Konstytucyjnego 1999 r., nr 3, s. 215.

13 T. Dębowska-Romanowska, Prawo finansowe część konstytucyjna wraz z częściq ogólnq, Warszawa 2010, s. 245.

14 T. Dębowska-Romanowska, Prawne i pozaprawne uwarunkowania skuteczności gwarancji wynikajqcych z art. 167 ust. 1 i 4 Konstytucji, [w:] M. Izdebski, A. Nelicki, I. Zachariasz (red.), Finanse komunalne a Konstytucja, Warszawa 2012, s. 35.

15 A. Borodo, Samorzq̨ terytorialny. System prawnofinansowy, Warszawa 2006, s. 150.

16 Projekt ustawy o zmianie ustawy o dochodach jednostek samorządu terytorialnego z dnia 1 lipca 2016 r., Druk Sejmowy z 2016 r. nr 718. 
nowelizacją ustawy o dochodach jednostek samorządu terytorialnego z dnia 23 października 2014 r. (opublikowanej 14 listopada 2014r.). Nowy mechanizm korekcyjno-wyrównawczy polega na tym, że ustala się różnicę pomiędzy sumą: części wyrównawczej subwencji ogólnej, wyliczonej na dany rok budżetowy na podstawie art. 24 ust. 1-8, części regionalnej subwencji ogólnej obliczonej według art. 70b oraz dotacji celowej ustalonej na dany rok budżetowy zgodnie z art. 70c, a sumą części wyrównawczej i części regionalnej subwencji ogólnej, którą otrzymałyby województwa na mocy przepisów obowiązujących przed dniem 14 listopada 2014 r. Jeżeli dla określonego województwa różnica jest dodatnia, to wówczas część regionalna subwencji ogólnej podlega zmniejszeniu o tę kwotę. Podlega ona podziałowi między województwa, dla których powyższa różnica jest ujemna.

Dodatkowym instrumentem, który ma zapewnić, że dochody województw nie ulegną zmniejszeniu w porównaniu z rokiem 2014, jest dotacja celowa utworzona na lata 2017-2019 w budżecie państwa z przeznaczeniem na dofinansowanie budowy i przebudowy, remontu, utrzymania, ochrony i zarządzania drogami wojewódzkimi, których zarządcą jest zarząd województwa. Planowana w 2017 r. kwota miałaby wynosić $225 \mathrm{mln}$ zł. Rezerwa celowa w budżecie państwa przeznaczona na ww. dotację w kolejnych dwóch latach, zostanie ustalona w ustawie budżetowej w takiej wysokości, aby mogła zapewnić pozyskanie przez województwa dochodów $\mathrm{z}$ tytułu części wyrównawczej i części regionalnej subwencji ogólnej pomniejszonej o wpłaty do budżetu państwa z przeznaczeniem na część regionalną subwencji ogólnej, na porównywalnym poziomie dochodów $\mathrm{z}$ tych tytułów wyliczonych w oparciu o art. 24 i art. 25 ustawy o dochodach jednostek samorządu terytorialnego $\mathrm{w}$ brzmieniu obowiązującym przed dniem 14 listopada 2014 r., po odliczeniu wpłat do budżetu państwa z przeznaczeniem na część regionalną subwencji ogólnej obliczonych na mocy uchylonego już obecnie art. 31 wspomnianej ustawy.

Według nowego proponowanego brzmienia art. 7c omawianą rezerwę rozdziela Minister Finansów między województwa, których powierzchnia dróg wojewódzkich w przeliczeniu na jednego mieszkańca 
województwa jest wyższa od powierzchni dróg wojewódzkich w kraju w przeliczeniu na jednego mieszkańca kraju. Sposób rozdziału tej kwoty będzie się odbywać według obowiązującego art. 70c ust. 4 .

Dla nowych jednostek samorządu terytorialnego proponuje się wprowadzenie przepisu, zgodnie z którym Minister Finansów nie dokonuje podziału określonej części subwencji ogólnej, jeżeli kwota części wyrównawczej, równoważącej i regionalnej subwencji ogólnej wynikająca $\mathrm{z}$ podziału ustalonego $\mathrm{w}$ oparciu o dotychczasowy art. 39 ust. 1 pkt 1, jest niższa od minimalnego wynagrodzenia za pracę ustalonego na dany rok budżetowy.

Wprowadzenie tymczasowych rozwiązań prawnych w zakresie finansów jednostek samorządu terytorialnego uzasadnia się koniecznością dostosowania nowych regulacji dotyczących mechanizmu korekcyjno-wyrównawczego do zreformowanego systemu finansowo-gospodarczego. Zdaniem autorów omawianego projektu zaproponowane przepisy wdrażają zalecenia Trybunału Konstytucyjnego ujęte w orzeczeniu z dnia 4 marca 2014 r., sygn. akt K 13/11, odnoszące się do zmiany zasad wyrównywania dochodów samorządów województw. Projektodawcy stwierdzają, że projekt uwzględnia:

- podwyższenie progów dochodowych województw skutkujących powstaniem obowiązku wpłat do budżetu oraz zmniejszenie nadwyżki przeznaczonej na wpłaty,

- ustalenie maksymalnego poziomu wysokości wpłat województw do budżetu państwa,

- wprowadzenie takiego mechanizmu obliczania wpłat, który nie doprowadzi do obniżenia poziomu dochodów województw dokonujących wpłat,

- dostosowanie wysokości wpłat do rzeczywistej kondycji finansowej samorządów poprzez możliwość obniżenia wpłat województwa w trakcie roku budżetowego w sytuacji, gdy osiągają niższe dochody podatkowe,

- zmianę reguły podziału części regionalnej subwencji tworzonej z tychże wpłat, którą będą otrzymywać tylko te z województw, których dochody podatkowe powiększone o subwencję wyrów- 
nawczą nie przekraczają 125\% średnich dochodów podatkowych w kraju; subwencji regionalnej nie otrzymają województwa dokonujące wpłat.

Założeniem i celem proponowanych zmian jest zapewnienie województwom środków w takiej kwocie, którą uzyskałyby na podstawie przepisów ustawy o dochodach jednostek samorządu terytorialnego, obowiązujących w brzmieniu przed dniem 14 listopada 2014 r.

Województwa samorządowe, oceniając analizowany projekt ustawy o dochodach jednostek samorządu terytorialnego ${ }^{17}$, opowiadały się za skróceniem okresu obowiązywania przepisów tymczasowych, obawiając się, że mogą one niekorzystnie wpłynąć na ich plany inwestycyjne i rozwojowe. Zastrzeżenia wyrażane były też $\mathrm{w}$ odniesieniu do proponowanego brzmienia art. 70c, zgodnie z którym województwa dokonujące wpłat byłyby włączone do podziału rezerwy celowej. Jednakże zdaniem autorów projektu nowelizacji omawianej ustawy uwzględnienie w podziale rezerwy województw dokonujących wpłat nie będzie się odbywać kosztem innych województw.

Natomiast zagadnienia związane z planowaniem długoterminowym zawiera art. 4 projektu, w którym została uregulowana kwestia opiniowania w Wieloletniej Prognozie Finansowej kwot z tytułu części regionalnej subwencji ogólnej. Według jednej z opinii projekt powinien uwzględniać jako istotne kryterium wyliczenia podstawy subwencji ogólnej, kryterium gęstości dróg wojewódzkich oraz kryterium gęstości linii kolejowych. Jednak w obecnie zaproponowanym systemie finansowania jednostek samorządu terytorialnego to kryterium jest podstawowym kryterium podziału rezerwy celowej, która zapewni uzupełnienie dochodów województw na realizację ich zadań. Trwałe rozwiązania systemowe muszą być dostosowane do reform gospodarczych, które będą miały wpływ na poziom dochodów jednostek samorządu terytorialnego.

17 Raport z konsultacji do projektu ustawy o zmianie ustawy o dochodach jednostek samorządu terytorialnego z dnia 1 lipca 2016 r., www.sejm.gov.pl (dostęp: 13.07.2016 r.). 


\section{Uwagi końcowe}

System wyrównywania poziomu dochodów jednostek samorządu terytorialnego nie jest regulowany przez prawo unijne. Uregulowanie tego zagadnienia zostało pozostawione do rozstrzygnięcia przez ustawodawcę narodowego, który może stosować w tym celu dotacje, subwencje lub inne działania równoważące. Do tej kwestii odnosi się jednak ratyfikowana przez Polskę Europejska Karta Samorządu Lokalnego ${ }^{18}$, stwierdzając w art. 9 ust. 5, że „ochrona społeczności lokalnych, finansowo słabszych, wymaga zastosowania procedur wyrównawczych lub działań równoważących, mających na celu korygowanie skutków nierównego podziału potencjalnych źródeł dochodów, a także wydatków, jakie te społeczności ponoszą. Procedury lub działania tego typu nie powinny ograniczać swobody podejmowania decyzji przez społeczności lokalne w zakresie ich uprawnień własnych.” Kategorycznym wymogiem Karty zawartym w ust. 5 art. 9 jest skonstruowanie procedur wyrównawczych w sposób zobiektywizowany, aby nie ograniczały one samodzielności finansowej samorządów terytorialnych.

Mechanizm wpłat zamożniejszych jednostek samorządu terytorialnego na system wyrównywania jest stosowany m.in. w Danii. Gminy, w których zapotrzebowanie na środki finansowe ustalane na jednego mieszkańca jest niższe od średniej krajowej, dofinansowują gminy mające wyższe zapotrzebowanie na środki finansowe od średniej krajowej. Niezależnie od powyższego kryterium środki wyrównawcze przysługują samorządom ze względu na posiadany niższy niż średnia krajowa współczynnik obliczany jako iloraz sumy dochodów podlegających opodatkowaniu podatkiem dochodowym od osób fizycznych oraz 6,5\% wartości gruntów opodatkowanych podatkiem gruntowym przez liczbę mieszkańców każdej gminy. Kwota subwencji ogólnej i wyrównawczej nie przekracza $10 \%$ globalnej sumy wpływów

18 Europejska Karta Samorządu Lokalnego sporządzona w Strasburgu dn. 15 października 1985 r. (Dz.U. z 1994 r., nr 124, poz. 607 ze sprost.). 
budżetowych gmin ${ }^{19}$. Subwencje ogólne są przyznawane przez państwo dopiero po zastosowaniu mechanizmów wyrównujących poziom dochodów samorządów terytorialnych ${ }^{20}$.

W państwach europejskich środki na wyrównywanie finansowe przekazywane jest w całości z budżetu państwa. Do ustalenia wysokości tych kwot stosowane są zróżnicowane kryteria. Przykładowo w Wielkiej Brytanii przy obliczaniu dotacji globalnych uwzględnia się stałe kryteria, powodujące powstawanie różnych wielkości kosztów realizacji zadań. Należy do nich np. liczba ludności w rozbiciu wiekowym, liczba domów, mieszkań, długość dróg ${ }^{21}$.

Wyrównywanie poziomu dochodów samorządów terytorialnych może się również odbywać za pomocą odpowiedniej konstrukcji udziałów w podatkach państwowych. Przykładowo w RFN rozdział wpływów podatkowych pomiędzy federacje, kraje związkowe i gminy jest związany z systemem wyrównań finansowych (Finanzausgleichsystem). Ma on na celu wyrównywanie niekorzystnych skutków podziału środków finansowych za pomocą tzw. kompensacji finansowej polegającej na rozdziale środków pieniężnych przez kraj związkowy na rzecz gmin (kompensacja pionowa) oraz na redystrybucji środków wśród gmin (kompensacja pozioma) ${ }^{22}$. W ramach wyrównania pionowego poszczególne kraje określają wysokość udziału gmin we wpływach kraju w podatkach wspólnych, a następnie dokonują rozdziału tych środków

19 M. Kowerski, Samorzq̨d lokalny w Danii, „Samorząd Terytorialny” 1998 r., nr 7-8, s. $156-157$.

20 Local Finance in the Fifteen Countries of the European Union, Bruksela-Paryż 1997, s. 61.

21 N. Gajl, Finanse i gospodarka lokalna na świecie, Warszawa 1993, s. 251; J. Stankiewicz, Wybrane zagadnienia władzy lokalnej i finansów lokalnych Wielkiej Brytanii, [w:] E. Ruśkowski (red.), Finanse komunalne $w$ wybranych krajach europejskich, Białystok 1997, s. 91; J.G. Gibson, P.A. Watt, British Local Government Current Expenditure Change and Block Grant, Financial Problems of Local Economy, „Acta Universitatis Lodziensis. Folia Iuridica” 1992, nr 49, s. 85 i n.

K. Waechter, Kommunalrecht, Köln-Berlin-Bonn-München 1997, s.164. 
pomiędzy gminy na podstawie zobiektywizowanych kryteriów obejmujących zapotrzebowanie finansowe gminy i jej siłę finansową ${ }^{23}$.

W Polsce również obowiązywał model udziałów realizowany w latach 1991-1996, w którym udziały stanowiły instrument wyrównywania poziomu dochodów samorządów gminnych. Model wprowadzany stopniowo od 1996 r. zakłada odejście od wykonywania przez udziały funkcji wyrównawczej.

W ramach reformy systemu finansowania jednostek samorządu terytorialnego należy rozważyć, który z modeli wyrównywania poziomu ich dochodów byłby najbardziej korzystny dla dalszego rozwoju gospodarki lokalnej i regionalnej. Czy powinien to być model wyłącznie pionowy, czy mieszany (zarówno pionowy, jak i poziomy). Zmiany powinny jednak zmierzać w kierunku zwiększania samodzielności finansowej jednostek samorządu terytorialnego. Jeżeli w takim modelu obowiązywałyby nadal wpłaty jednostek samorządu terytorialnego, to wydaje się, że ich znaczenie uległoby zmniejszeniu.

\section{Bibliografia:}

Bogucka-Felczak M., System korekcyjno-wyrównawczy - postulaty de lege ferenda, „Finanse Komunalne” 2014, nr 1-2, s. 92-105.

Borodo A., Samorzq̨ terytorialny. System prawnofinansowy, Wydawnictwo Prawnicze LexisNexis, Warszawa 2006.

Dębowska-Romanowska T., Prawne i pozaprawne uwarunkowania skuteczności gwarancji wynikajqcych z art. 167 ust. 1 i 4 Konstytucji, [w:] M. Izdebski, A. Nelicki, I. Zachariasz (red. nauk.), Finanse komunalne a Konstytucja, Biuro Trybunału Konstytucyjnego, Warszawa 2012.

Dębowska-Romanowska T., Prawo finansowe część konstytucyjna wraz z częściq ogólnq, Wydawnictwo C.H. Beck, Warszawa 2010.

Gajl N., Finanse i gospodarka lokalna na świecie, Państwowe Wydawnictwo Ekonomiczne, Warszawa 1993.

23 R. Stober, Kommunalrecht in der Bundesrepublik Deutschland, Stuttgart-BerlinKöln, 1992, s. 213. 
Gibson J.G., Watt P. A., British Local Government Current Expenditure Change and Block Grant, Financial Problems of Local Economy, „Acta Universitatis Lodziensis. Folia Iuridica” 1992, nr 49.

Kamińska D., Nelicki A., Asystemowość wyrównywania dochodów jednostek samorzq̨u terytorialnego, [w:] M. Izdebski, A. Nelicki, I. Zachariasz (red. nauk.), Finanse komunalne a Konstytucja, Biuro Trybunału Konstytucyjnego, Warszawa 2012.

Kowerski M., Samorzq̨d lokalny w Danii, „Samorząd Terytorialny” 1998, nr 7-8, s. $148-159$.

Local Finance in the Fifteen Countries of the European Union, Bruksela-Paryż 1997.

Miesztalski M., Dysfunkcje w systemie wyrównywania dochodów jednostek samorzqdu terytorialnego, [w:] M. Izdebski, A. Nelicki, I. Zachariasz (red. nauk.), Finanse komunalne a Konstytucja, Biuro Trybunału Konstytucyjnego, Warszawa 2012.

Nelicki A., Uwagi na temat konstytucyjności mechanizmu „Janosikowego” wświetle wyroku Trybunału Konstytucyjnego z 25 lipca 2006 r., [w:] M. Izdebski, A. Nelicki, I. Zachariasz (red. nauk.), Finanse komunalne a Konstytucja, Biuro Trybunału Konstytucyjnego, Warszawa 2012.

Stankiewicz J., Wybrane zagadnienia władzy lokalnej i finansów lokalnych Wielkiej Brytanii, [w:] E. Ruśkowski (red.), Finanse komunalne w wybranych krajach europejskich,Temida 2, Białystok 1997.

Stober R., Kommunalrecht in der Bundesrepublik Deutschland, Stuttgart-BerlinKöln, 1992.

Waechter K., Kommunalrecht, Köln-Berlin-Bonn-München 1997. 